\title{
Communicating with Local Elected Officials ${ }^{1}$
}

\author{
Rick Wayne Telg and Shelli Rampold ${ }^{2}$
}

This EDIS document is part of a series on communicating with elected officials. The series includes the following EDIS documents:

\section{Speaking with Policymakers about Current Issues (http://} edis.ifas.ufl.edu/wc152)

\section{Strategies for Engaging and Communicating with Elected Officials (http://edis.ifas.ufl.edu/wc324)}

3. Visiting Elected Officials (http://edis.ifas.ufl.edu/wc318)

\section{Introduction}

Elected officials at the local, state, and national levels create policies and laws that can impact the agricultural and natural resources (ANR) sector in Florida. This publication (a) discusses how county commissioners prepare to vote on ANR policies, (b) identifies factors that impact county commissioners' decision-making about ANR policy decisions, (c) identifies sources county commissioners' use to gather ANR information, and (d) discusses how information from Extension faculty and other individuals can be presented to effectively inform elected officials on important ANR topics, explain complex processes, and educate them about Extension programs.

\section{Educating and Advocating}

Extension faculty can educate without advocating. Educating provides individuals with information about complex perspectives and provides options for an associated action
(Lamm, 2013). Advocating takes a stand on an issue. In the Extension setting, advocating is typically a special role for volunteers or advisory board members; advocating is not a role of Extension faculty because advocating or persuading for an issue would be considered lobbying. An example of educating elected officials is providing science-based facts, such as communicating about the benefits of using the "right plant, right place" for Florida-friendly landscapes, or of using smart irrigation systems to lower water use and cut costs.

\section{Information Florida's County Commissioners Seek Before Voting on ANR Policy}

In early 2018, a link to an online questionnaire was emailed to all Florida county commissioners who had valid email addresses $(N=285)$. A total of 45 responded for a $16 \%$ response rate. County commissioners were asked a number of questions regarding (a) how they prepare to vote on ANR policies, (b) factors that impact their decision-making about ANR policies, (c) their communication preferences (how they preferred to be communicated to), and (d) the sources they use to be informed about ANR issues. Results from the survey that pertain to how county commissioners prepare to vote on ANR issues and factors that impact their decision-making are presented in this section.

1. This document is AEC653, one of a series of the Department of Agricultural Education and Communication, UF/IFAS Extension. Original publication date November 2018. Visit the EDIS website at https://edis.ifas.ufl.edu for the currently supported version of this publication.

2. Ricky Wayne Telg, professor; and Shelli Rampold, research coordinator, Department of Agricultural Education and Communication; UF/IFAS Extension, Gainesville, FL 32611.

The Institute of Food and Agricultural Sciences (IFAS) is an Equal Opportunity Institution authorized to provide research, educational information and other services only to individuals and institutions that function with non-discrimination with respect to race, creed, color, religion, age, disability, sex, sexual orientation, marital status, national origin, political opinions or affiliations. For more information on obtaining other UF/IFAS Extension publications, contact your county's UF/IFAS Extension office. 


\section{Preparing to Vote on Policy}

County commissioners were provided a series of statements regarding how they prepare to vote on a policy that impacts agriculture and natural resources. County commissioners agreed or strongly agreed with all statements. They indicated the highest agreement with the statements "I would seek to fully understand the policy," and "I would seek factual information from multiple sources" (see Table 1). Findings indicate county commissioners seek out information, specifically factual information, from multiple sources before they vote on a policy that impacts Florida's ANR sector.

\section{Factors Impacting Decision-Making}

County commissioners were asked to indicate the extent to which select factors impact their decision-making when making ANR policy decisions. County commissioners identified communication from a farmer or rancher impacted by a proposed policy as the factor with the highest impact on their decision-making (see Table 2). This finding suggests it may be important for communicators to consider who provides information to elected officials. County commissioners valued communication from farmers/ranchers impacted by a proposed policy more than other information sources.

\section{The "You" You Represent}

If you are an active, concerned citizen in your community and must address elected officials in your capacity as an Extension faculty, it is recommended that you declare the "you" you are representing at a local board, city council, or county commissioners meeting. Are you a "concerned citizen/constituent," or are you a "representative of your university"? For issues that could impact your role as an Extension faculty member, it is recommended that you present yourself in the capacity of an Extension faculty member and not as a "constituent," as well as provide information with the intention of educating rather than advocating. You may present yourself as a constituent on issues that do not relate to your role in Extension. However, when you are in a constituent role, you should not wear your University of Florida Institute of Food and Agricultural Sciences (UF/IFAS) logo shirt or your official name badge so that local elected officials are not confused about your role or who you represent (concerned constituent or UF/IFAS Extension representative).

\section{Other Considerations Impacting Elected Officials' Decision-Making}

As you prepare to talk to elected officials, be aware that elected officials are concerned about the following areas:

- Getting elected: Unless there is a term limit for an elected official, an elected official is either just finishing an election campaign, preparing for a campaign, or actively campaigning for re-election. Positive topics that could be touted on the campaign trail, such as programs having positive educational, social, or economic impacts, are often popular with elected officials.

- Avoiding controversy: Elected officials want to avoid controversy or votes that will haunt them later. If possible, avoid topics that could place elected officials in difficult situations. If it is necessary to bring forward a controversial item, possibly target non-election years to do so.

In addition, you should consider the following points when you present information to elected officials:

- Help them avoid information overload. They get information from many sources every day. Keep everything as simple as possible, and do not provide more information than they need (Cairney \& Richard, 2017; Gregrich, 2003). You do not need to bring a 16-page report when a one-page document will do (information on what content to provide in a one-page "leave-behind" document is provided in the following EDIS publication in this series: Visiting Elected Officials).

- Be part of the solution. Do not point out problems unless you have a scientific-based solution. When possible, be willing to take the time and effort to solve the issue.

- Provide good photo opportunities, press coverage, and social media coverage. As previously stated, elections are often on the minds of elected officials, and their interests are often fitted to an election cycle (Brownson, Royer, Edwing, \& McBride, 2006). As such, the official is more likely to come to your event and to assist you in the future if you can provide them positive opportunities for photos and media coverage.

- Be a credible source. Your honesty, integrity, and credibility are paramount to communicating effectively with elected officials (Cairney \& Kwiatkowski, 2017). 


\section{County Commissioners' Communication Preferences and Information Sources}

The following section provides findings from the Florida county commissioners survey that focused on the commissioners' communication preferences and the media sources they used to collect information on ANR issues.

\section{Communication Preferences}

Florida county commissioners most preferred for constituents to communicate information to them via face-to-face scheduled meetings or email. Phone or conference calls and written letters were only moderately preferred. The communication method least preferred by county commissioners was social media platforms (see Table 3 ). These findings indicate that constituents should schedule face-to-face meetings or use email when communicating with county commissioners. Also, note that all written materials are subject to open public records, which may provide more rationale to convey information to elected officials in a face-to-face meeting.

The county commissioners who indicated some degree of preference for communicating via social media identified Facebook as the most preferred of the social media platforms. Twitter, Google, and LinkedIn were only slightly preferred, and the remaining social media platforms were not at all preferred (see Table 4).

\section{Information Sources}

Overall, county commissioners utilized media sources occasionally ( $25 \%-50 \%$ of the time) when gathering information about agriculture and natural resources. The media sources used most frequently included internet news sources, agricultural specialists, and community events. The media source used least often by county commissioners was national network TV news channels (see Table 5).

Overall, county commissioners utilized organizations/ agencies occasionally to gather information about food and agriculture. The organizations that county commissioners used most frequently were the University of Florida Institute of Food and Agricultural Services (UF/IFAS), local UF/ IFAS Extension offices, US Department of Agriculture, and Florida Farm Bureau (see Table 6).

\section{Summary}

This document provides information on Extension faculty members' roles as educators, not advocates, for ANR issues in Florida. Florida county commissioners used multiple, factual sources to fully understand an ANR issue before voting on a policy. Contact from a farmer/rancher affected by a proposed policy was most impactful for county commissioners when making a decision about that policy. Regarding their preferred methods of communication, county commissioners preferred that constituents communicate to them through face-to-face meetings or email. Lastly, county commissioners used internet news sources and agricultural specialists more than other sources to gather ANR information.

\section{References}

Brownson, R. C., Royer, C., Ewing, R., \& McBride, T. D. (2006). "Researchers and policymakers: Travelers in parallel universes." American Journal of Preventative Medicine, 30(2), 164-172. doi:10.1016/j.amepre.2005.10.004

Cairney, P., \& Kwiatkowski, R. (2017). "How to communicate effectively with policymakers: Combine insights from psychology and policy studies." Palgrave Communications 3(1), doi:10.1057/s41599-017-0046-8

Gregrich, R. J. (2003). "A note to researchers: Communicating science to policy makers and practitioners." Journal of Substance Abuse Treatment, 25, 233-237. doi:10.1016/ S0740-5472(03)00120-X

Lamm, A. J. (2013). Speaking with policymakers about current issues. AEC489. Gainesville: University of Florida Institute of Food and Agricultural Sciences. http://edis.ifas. ufl.edu/wc152 
Table 1. County commissioners' agreement with how they prepare to vote on agriculture or natural resource policy.

\begin{tabular}{|c|c|c|c|}
\hline Item & $M$ & $S D$ & Interpretation \\
\hline I would seek to fully understand the policy. & 4.60 & .54 & Strongly agree \\
\hline I would seek factual information. & 4.60 & .63 & Strongly agree \\
\hline I would seek information from multiple sources. & 4.57 & .55 & Strongly agree \\
\hline $\begin{array}{l}\text { I would consider both the positive and negative implications } \\
\text { that could result. }\end{array}$ & 4.52 & .63 & Strongly agree \\
\hline I would ask others for their opinion on the matter. & 4.31 & .72 & Agree \\
\hline I would discuss my opinions with others. & 4.14 & .87 & Agree \\
\hline
\end{tabular}

Note: Real limits: 1.00 to $1.49=$ strongly disagree, 1.50 to $2.49=$ disagree, 2.50 to $3.49=$ neither agree nor disagree, 3.50 to $4.49=$ agree, 4.50 to 5.00 = strongly agree

Table 2. Impact of factors on county commissioners' decision-making regarding agricultural and natural resource policy decisions.

\begin{tabular}{|c|c|c|c|}
\hline Item & $M$ & $S D$ & Interpretation \\
\hline $\begin{array}{l}\text { Communication from a farmer or rancher impacted by a proposed } \\
\text { policy. }\end{array}$ & 3.85 & 1.01 & High impact \\
\hline $\begin{array}{l}\text { Scientific information from a university regarding the potential } \\
\text { impact of a proposed policy. }\end{array}$ & 3.69 & .84 & High impact \\
\hline $\begin{array}{l}\text { Communication from a president or a director of an agricultural } \\
\text { association impacted by a proposed policy. }\end{array}$ & 3.50 & .83 & High impact \\
\hline $\begin{array}{l}\text { Communication from constituents other than agricultural } \\
\text { organizations or farmers/ranchers regarding a proposed policy. }\end{array}$ & 2.87 & .95 & Moderate impact \\
\hline
\end{tabular}

Note: Real limits: 1.00 to $1.49=$ no impact, 1.50 to $2.49=$ slight impact, 2.50 to $3.49=$ moderate impact, 3.50 to $4.49=$ high impact, 4.50 to $5.00=$ very high impact

Table 3. Florida county commissioners' preferences regarding how constituents communicate information to them $(N=44)$.

\begin{tabular}{|l|c|c|c|}
\hline \multicolumn{1}{|c|}{ Communication Method } & M & \multicolumn{1}{c|}{ Interpretation } \\
\hline Face-to-face scheduled meeting & 3.59 & 1.02 & Very preferred \\
\hline Email & 3.50 & 1.09 & Very preferred \\
\hline Phone or conference call & 3.16 & .99 & Moderately preferred \\
\hline Written letter & 2.89 & 1.04 & Moderately preferred \\
\hline Social media platforms & 2.11 & 1.13 & Slightly preferred \\
\hline Other & 1.86 & 1.22 & Slightly preferred \\
\hline
\end{tabular}

Note: Real limits: 1.00 to $1.49=$ not at all preferred, 1.50 to $2.49=$ slightly preferred, 2.50 to $3.49=$ moderately preferred, 3.50 to $4.49=$ very preferred, 4.50 to $5.00=$ extremely preferred

Table 4. Florida county commissioners' preferences regarding social media platforms as methods of communication $(\mathrm{N}=25)$.

\begin{tabular}{|l|l|l|l|}
\hline \multicolumn{1}{|c|}{ Social Media Platform } & M & SD & \multicolumn{1}{c|}{ Interpretation } \\
\hline Facebook & 3.08 & 1.32 & Moderately preferred \\
\hline Twitter & 1.76 & 1.01 & Slightly preferred \\
\hline Google+ & 1.67 & .96 & Slightly preferred \\
\hline Linkedln & 1.50 & .89 & Slightly preferred \\
\hline YouTube & 1.46 & .66 & Not at all preferred \\
\hline Pinterest & 1.29 & .62 & Not at all preferred \\
\hline Instagram & 1.29 & .55 & Not at all preferred \\
\hline Snapchat & 1.21 & .51 & Not at all preferred \\
\hline Tumblr & 1.17 & .49 & Not at all preferred \\
\hline Buzzfeed & 1.13 & .46 & Not at all preferred \\
\hline $\begin{array}{l}\text { Note: } \text { Real limits: } 1.00 \text { to } 1.49=\text { not at all preferred, } 1.50 \text { to } 2.49=\text { slightly preferred, } 2.50 \text { to } 3.49=\text { moderately preferred, } 3.50 \text { to } 4.49=\text { very } \\
\text { preferred, } 4.50 \text { to } 5.00=\text { extremely preferred }\end{array}$ & & \\
\hline
\end{tabular}


Table 5. Florida county commissioners' use of media sources when gathering information about agriculture and natural resources $(\mathrm{N}=45)$.

\begin{tabular}{|c|c|c|c|}
\hline Media Source & $M$ & $S D$ & Interpretation \\
\hline Internet news sources & 3.47 & 1.12 & Occasionally \\
\hline Agricultural specialists & 3.18 & 1.23 & Occasionally \\
\hline Community events & 3.13 & 1.16 & Occasionally \\
\hline Technical reports & 2.98 & 1.22 & Occasionally \\
\hline Fact sheets & 2.96 & 1.09 & Occasionally \\
\hline Seminars or conferences & 2.67 & 1.13 & Occasionally \\
\hline News radio channels & 2.42 & 1.31 & Rarely \\
\hline Newspaper & 2.40 & 1.10 & Rarely \\
\hline Peer-reviewed journal articles & 2.38 & 1.23 & Rarely \\
\hline Social media & 2.33 & 1.23 & Rarely \\
\hline $\begin{array}{l}\text { National cable TV news channels (Fox News, MSNBC, CNN, } \\
\text { etc.) }\end{array}$ & 2.33 & 1.17 & Rarely \\
\hline TV programs (not news) & 2.16 & .93 & Rarely \\
\hline Lobbyists & 2.02 & .94 & Rarely \\
\hline Magazine & 2.00 & .98 & Rarely \\
\hline National network TV news channels (ABC, CBS, NBC, etc.) & 1.98 & 1.10 & Rarely \\
\hline
\end{tabular}

Table 6. Organizations or agencies used by county commissioners to gather information about food and agriculture $(\mathrm{N}=43)$.

\begin{tabular}{|c|c|c|c|}
\hline Organization/Agency & $M$ & $S D$ & Interpretation \\
\hline University of Florida/Institute of Food and Agricultural Services (UF/IFAS) & 3.56 & 1.14 & Often \\
\hline $\begin{array}{l}\text { Local Institute of Food and Agricultural Services Extension Offices (UF/IFAS } \\
\text { Extension) }\end{array}$ & 3.33 & 1.30 & Occasionally \\
\hline US Department of Agriculture & 3.21 & 1.17 & Occasionally \\
\hline Florida Farm Bureau & 3.21 & 1.23 & Occasionally \\
\hline Florida Department of Agriculture and Consumer Services & 2.79 & 1.01 & Occasionally \\
\hline Florida Cattlemen's Association & 2.77 & 1.38 & Occasionally \\
\hline $\begin{array}{l}\text { UF/IFAS Center for Public Issues Education in Agriculture and Natural } \\
\text { Resources (PIE Center) }\end{array}$ & 2.70 & 1.44 & Occasionally \\
\hline Florida Department of Health & 2.35 & 1.02 & Rarely \\
\hline Florida Fruit and Vegetable Association & 1.95 & 1.08 & Rarely \\
\hline Florida Nursery, Growers and Landscape Association & 1.93 & 1.11 & Rarely \\
\hline Florida Diary Farmers & 1.77 & .95 & Rarely \\
\hline Florida Fertilizer and Agrichemical Association & 1.74 & 1.00 & Rarely \\
\hline
\end{tabular}

